\title{
Comparative Investigation of Amino Acids Content in the Dry Extracts of Juno bucharica, Gladiolus Hybrid Zefir, Iris Hungarica, Iris Variegata and Crocus Satious Raw Materials of Ukrainian Flora
}

 \\ Victoriya Georgiyants ${ }^{3}$ (D) \\ 1 Department of Botany, National University of Pharmacy, 4 Valentinivska, 61168 Kharkiv, Ukraine; \\ Mykhailenko.farm@gmail.com \\ 2 Department of Analytical and Toxicological Chemistry, Lithuanian University of Health Sciences, \\ A. Mickevičiaus 9, LT 44307 Kaunas, Lithuania; liudasivn@gmail.com \\ 3 Department of Pharmaceutical Chemistry, National University of Pharmacy, 4 Valentynivska, 61168 Kharkiv, \\ Ukraine; vania.bezruk@gmail.com (I.B.); vgeor@nuph.edu.ua (V.G.) \\ 4 Department of Pharmaceutical, Organic and Bioorganic Chemistry, Danylo Halytsky Lviv National Medical \\ University, 69 Pekarska, 79010 Lviv, Ukraine \\ 5 Department of Public Health, Dietetics and Lifestyle Disorders, Faculty of Medicine, \\ University of Information Technology and Management in Rzeszow, Sucharskiego 2, \\ 35-225 Rzeszow, Poland \\ * Correspondence: dr_r_lesyk@org.lviv.net; Tel.: +38-067-703-8010
}

Received: 15 December 2019; Accepted: 5 February 2020; Published: 7 February 2020

\begin{abstract}
The aim of this research was the comparative study of the amino acids content in the dry extracts of Iridaceae plants of Ukrainian flora: Juno bucharica leaves and corms, Gladiolus hybrid Zefir leaves, Iris hungarica and Iris variegata rhizomes, and Crocus sativus stigmas, flowers, leaves and corms. A gas chromatography-mass spectrometry (GC-MS) method has been used. Separation of amino acids in the samples was carried out using a Shimadzu GC-MS-QP2010 equipped with an Rxi-5ms (Restek Corporation capillary column (30 m long, $0.25 \mathrm{~mm}$ outer diameter and $0.25 \mu \mathrm{m}$ ) with a liquid stationary phase ( $5 \%$ diphenyl and $95 \%$ polysiloxane) after derivatization with $\mathrm{N}$-(t-butyldimethylsilyl)-N109 methyltrifluoroacetamide (MTBSTFA) reagent. The results obtained have shown that extracts from the aerial parts of plants investigated have a higher amino acid content and more diverse composition than the underground organs. Experimental data showed that Crocus leaves and Juno leaves extracts contain the highest general content of amino acids- $31.99 \mathrm{mg} / \mathrm{g}$ and $14.65 \mathrm{mg} / \mathrm{g}$ respectively. All samples showed a high content of L-pyroglutamic acid $(0.33-12.35 \mathrm{mg} / \mathrm{g})$. Moreover, Crocus leaves and Juno leaves extracts had the most suitable amino acids composition and are prospective for further pharmacological studies.
\end{abstract}

Keywords: Iridaceae; dry extracts; amino acids; GC-MS; derivatization

\section{Introduction}

Nowadays, a number of questions about evidence-based phytotherapy are under discussion [1-4]. The main way to give scientific explanation to the pharmacological effects of natural pharmaceuticals is through the standardization of plant raw material and the recognition of the role of certain biologically active substances or their groups for pharmacological action. In accordance with modern concepts about the contribution of plant constituents to pharmacological activity, amino acids, as minor components, 
are very important for different kinds of action [5-7]. Sometimes, the presence/absence of certain amino acids is the key factor influencing the central nervous system, thyroid gland, etc. [8,9].

Various plant species of the Iridaceae family are known for their magnificent decorative flowers as they are widely cultivated and wild-growing in Europe countries. At the same time, some Iridaceae plants are also known to be widely used as food, condiments or as medicinal plants [10-12]. Thus a high pharmacoligical potential was discovered for extracts and active constituents of plants from genes Crocus, Iris, Gladiolus and Juno [13-17]. Anti-inflammatory, phytoestrogenic, antidiabetic, hepatoprotective, hypolipidemic [10-12], antioxidant [13,14,17,18], antimicrobial [16,18] and anticancer [19,20] activities are described for some plants of these genes. C. sativus stigma [21], petal, stamen, and flower [22] extracts show good antioxidant activity in vitro antioxidant models due to the presence of carotenoids crocins and phenolic compounds (derivatives of kempferol and quercetin). Extracts of C. sativus leaves showed higher antioxidant activity than petals [15]. Iris species are characterized by a high content of xanthon mangiferin and different flavonoids and isoflavones (apigenin, kampferol, quercetin, vitexin, tectoridin, nigricin and its glucosides), which determine the presence of antioxidant [13,14,23] and antiviral activity [24]. Isoflavones and their glycosides isolated from rhizomes of I. kashmiriana [25] and I. germanica [19], as well as the extracts of I. pseudopumila and I. florentina, have been reported [10] to have cytotoxic properties. Phytochemical investigations showed that in these plants there is the presence of isoflavones [10,11,19], flavones [10,11,13,16,22], xanthones [10,14], quinones, peltogynoids and stilbenes [10,13], fatty acids [15], carotenoids [11,12,20], triterpenes, iridals [10,26]. However, the composition of the amino acids of these plants materials belongs to this family has not been studied much $[27,28]$.

Separation and quantification of amino acids in a complex matrix such as herb material is a difficult task due to their high polarity with low volatilization and no chromophore groups. Furthermore, different techniques were developed and validated for their identification and quantification. Indirect methods are more popular and widely used. They include pre- or post-column derivatization with various reagents, for instance ninhydrin, ortho-phthalaldehyd (OPA) [29,30], phenyl isothiocyanate (PITC) [31], 2,4-dinitrofluorobenzene (DNFB), dimethylaminoazobenzene sulfonyl chloride (Dabsyl-Cl), 9-fluorenylmethyloxycarbonyl chloride (FMOC-Cl) [32], 9-fluorenylmethoxycarbonyl glycine chloride, and 6-aminoquinolyl-N-hydroxysuccinimidyl carbamate [33]. On other hand, direct methods are easier to apply and require no reagent. For instance, capillary electrophoresis equipped with an ultraviolet detector [34] — as well as a recently a new method of amino acids analysis — has been performed using UPLC-HILIC MS/MS method [35]. Furthermore, GC/MS is a promising method for the analysis of a wide range of amino acids due to remarkable chromatographic resolution combined with reproducible MS detection [36]. Some research [37,38] provides data on how the precision of quantification in analysis utilizing LC-MS can be compromised due to changes of ionization efficiency caused by matrix effects and the co-elution of metabolites. Such data hold true despite the presence of isotope-labeled internal standards, indicating a significant limitation to the development of quantitative untargeted LC/MS methods. LC methods are accurate enough and reliable but not eco-friendly. Furthermore, GC/MS provides the high sensitivity of the single quadrupole mass detector, reproducible ionization and fragmentation pattern of EI for a broad range of metabolite derivatives, informative mass spectra [39], as well as low maintenance cost $[40,41]$.

In Ukrainian flora, the Iridaceae family is represented by many plants both harvested and wild-growing. Among them Crocus sativus, Juno bucharica, Gladiolus hybrid Zefir, Iris hungarica and Iris variegata are very interesting as prospective phytopharmaceuticals sources. Taking into account the possible role of amino acids as pharmacological activity, we decided to perform a comparative investigation into the content of these constituents in chosen plant raw material of Iridaceae family representatives from Ukrainian flora. 


\section{Materials and Methods}

\subsection{Materials and Methods}

Analytical and chromatographic grade reagents were used and prepared according to the requirements of the State Pharmacopoeia of Ukraine [42] and European Pharmacopoeia [43]. Acetonitrile was purchased from Sigma-Aldrich GmbH (Karlsruhe, Germany). Purified water was produced by Millipore (Bedford, MA, USA) water purification system. A mix of L-amino standard acids (alanine, serine, valine, threonine, leucine, isoleucine, proline, aspartic acid, glutamic acid, lysine, methionine, phenylalanine, tyrosine) were purchased from Sigma-Aldrich GmbH (Steinheim, Germany). MTBSTFA was purchased from Sigma-Aldrich (St. Louis, MO, USA).

\subsection{Plant Raw Materials}

Leaves and corms of Juno bucharica (Foster) Vved (a voucher specimen CWU0056539), Gladiolus hybrid Zefir (a voucher specimen CWU0056538), Iris hungarica Waldst. et Kit. rhizomes (a voucher specimen CWU0056534), Iris variegata L. rhizomes (a voucher specimen CWU0056545) were harvested from the collection of botanical gardens of V. N. Karazin Kharkiv National University (Kharkiv, Ukraine) in May 2018. Crocus sativus (a voucher specimen CWU0056541-CWU005654) stigmas, flowers, leaves and corms were collected from a plantation in the village of Lyubimivka (Kahovka, Ukraine) in November 2017. All voucher specimens were verified by Yu. G. Gamulya and deposited at the Herbarium of V. N. Karazin Kharkiv National University, Kharkiv, Ukraine. The fresh plant material was air dried and crushed to obtain powder.

\subsection{Preparation of Extracts}

Powdered plant material (100 g) of Juno corm and leaves, Gladiolus and Crocus leaves, Crocus flowers and corms, and Iris species rhizomes were extracted with distilled water (1 L), on a water bath at $80^{\circ} \mathrm{C}$ for $2 \mathrm{~h}$ three times, extracts were filtered and concentrated using a rotavapor and then completely dried in a drying cabinet and preserved at $4{ }^{\circ} \mathrm{C}$ until further use.

C. sativus stigma powder ( $5 \mathrm{~g})$ was treated with hot distilled water $\left(500 \mathrm{~mL}, 80^{\circ} \mathrm{C}\right)$ and kept in a dark place for $24 \mathrm{~h}$. After collecting the resulting extracts, the raw material was treated again with distilled water $\left(500 \mathrm{~mL}, 4^{\circ} \mathrm{C}\right)$ and kept in a dark place for $24 \mathrm{~h}$. This maceration process was repeated a third time using $500 \mathrm{~mL}$ of distilled water at $4{ }^{\circ} \mathrm{C}$ and keeping the solution in a dark place for $24 \mathrm{~h}$.

\subsection{Sample Preparation and Derivatization}

Test solutions were prepared as follows: $0.1 \mathrm{~g}$ of dry extracts were weighed into a volumetric flask and extracted with methanol $(10 \mathrm{~mL})$ in an ultrasonic bath at room temperature $\left(20 \pm 2{ }^{\circ} \mathrm{C}\right)$ for $15 \mathrm{~min}$. The obtained solution was centrifuged for $10 \mathrm{~min}$ at $5000 \mathrm{rpm}$ at $25^{\circ} \mathrm{C}$. An amount of $500 \mu \mathrm{L}$ of supernatant was evaporated under nitrogen gas to dry residue. The resulting precipitate was dissolved in $100 \mu \mathrm{L}$ of acetonitrile and $100 \mu \mathrm{L}$ of MTBSTFA. This solution was heated at $100{ }^{\circ} \mathrm{C}$ for $2.5 \mathrm{~h}$ in a glycerol bath. Then, $1 \mu \mathrm{L}$ of the test solution was injected into a gas chromatograph.

Preparation of standard solutions. An amount of $100 \mu \mathrm{L}$ of the L-amino acids standards mixture (reference samples of alanine, serine, valine, threonine, leucine, isoleucine, proline, aspartic acid, glutamic acid, lysine, methionine, phenylalanine, tyrosine) were taken and dried under nitrogen gas to dry residue, then $100 \mu \mathrm{L}$ of acetonitrile and $100 \mu \mathrm{L}$ of MTBSTFA were added. The obtained solution was heated at $100{ }^{\circ} \mathrm{C}$ for $2.5 \mathrm{~h}$ in a glycerol bath.

\subsection{GC-MS Analysis}

The analyses were carried out using a SHIMADZU GC-MS-QP2010. The separation of amino acids was carried out using a Rxi-5ms capillary column (30 m long, $0.25 \mathrm{~mm}$ outer diameter and $0.25 \mu \mathrm{m}$ liquid-stationary phase thickness) (Restek Corporation, Bellefonte, PA) with a liquid stationary 
phase ( $5 \%$ diphenyl and $95 \%$ polysiloxane), and carrier gas helium. Oven temperature was set at $75{ }^{\circ} \mathrm{C}$ and kept for $5 \mathrm{~min}$, and then increased at $10{ }^{\circ} \mathrm{C} / \mathrm{min}$ to $290{ }^{\circ} \mathrm{C}$, then at $20^{\circ} \mathrm{C} / \mathrm{min}$ to $320^{\circ} \mathrm{C}$ and finally held at that temperature for $5 \mathrm{~min}$. The injector temperature was $260^{\circ} \mathrm{C}$. The injection was made in the mode split (splitter 1:20) at $260^{\circ} \mathrm{C}$ with an injection volume $1 \mu \mathrm{L}$. Mass spectra $(70 \mathrm{eV}$, electron impact mode) scan range of $\mathrm{m} / \mathrm{z} 35-500 \mathrm{amu}$ with mass scan time of $0.2 \mathrm{~s}$, interface temperature $280^{\circ} \mathrm{C}$. Flow column rate was $1.5 \mathrm{~mL} / \mathrm{min}$, pressure $100 \mathrm{kPa}$, total flow rate: $34.4 \mathrm{~mL} / \mathrm{min}$. The analytical run was in total $41 \mathrm{~min}$. The content of identified amino acids is presented in Table 1.

\subsection{Statistical Analyses}

Statistical analysis was performed via a one-way ANOVA analysis of variance followed by Tukey's multiple comparison test by using the software package Prism v.5.04 (GraphPad Software Inc., La Jolla, CA, USA). The value of $p<0.05$ was taken as the level of significance. 
Table 1. The content of free amino acids in Iridaceae dry aqueous plant extracts, $\mu \mathrm{g} / \mathrm{g}$.

\begin{tabular}{|c|c|c|c|c|c|c|c|c|c|c|c|}
\hline $\mathbf{N}$ & R.Time & $\begin{array}{l}\text { Name of Amino } \\
\text { Acid }\end{array}$ & $\begin{array}{c}\text { Gladiolus } \\
\text { Leaves }\end{array}$ & Juno Leaves & Crocus Leaves & $\begin{array}{l}\text { Crocus } \\
\text { Flowers }\end{array}$ & $\begin{array}{l}\text { Crocus } \\
\text { Stigma }\end{array}$ & Crocus Corms & $\begin{array}{l}\text { Juno } \\
\text { Corms }\end{array}$ & $\begin{array}{c}\text { Iris Hungarica } \\
\text { Rhizome }\end{array}$ & $\begin{array}{c}\text { Iris Variegato } \\
\text { Rhizome }\end{array}$ \\
\hline 1 & 14,98 & L-Alanine & $34.9 \pm 0.7$ & $1032.2 \pm 15.1$ & $2709.5 \pm 75.1$ & $156.3 \pm 1.7$ & $60.0 \pm 2.1$ & $204.1 \pm 2.1$ & $52.1 \pm 1.5$ & $\mathrm{n} / \mathrm{d}$ & $114.9 \pm 1.4$ \\
\hline 2 & 16,51 & $\mathrm{~L}$-Valine & $24.3 \pm 0.5$ & $1411.1 \pm 20.7$ & $3023.0 \pm 51.1$ & $105.8 \pm 2.1$ & $\mathrm{n} / \mathrm{d}$ & $458.7 \pm 19.3$ & $24.5 \pm 0.5$ & $\mathrm{n} / \mathrm{d}$ & $81.2 \pm 2.6$ \\
\hline 3 & 17,00 & L-Leucine & $\mathrm{n} / \mathrm{d}$ & $1016.2 \pm 18.5$ & $2401.5 \pm 75.2$ & $72.2 \pm 1.6$ & $\mathrm{n} / \mathrm{d}$ & $80.7 \pm 1.3$ & $\mathrm{n} / \mathrm{d}$ & $\mathrm{n} / \mathrm{d}$ & $\mathrm{n} / \mathrm{d}$ \\
\hline 4 & 17,34 & $\begin{array}{c}\text { Isoleucine } \\
\text { 4-Aminobutanoic }\end{array}$ & $\mathrm{n} / \mathrm{d}$ & $1049.2 \pm 25.4$ & $2322.5 \pm 67.8$ & $101.7 \pm 4.8$ & $\mathrm{n} / \mathrm{d}$ & $174.9 \pm 4.8$ & $31.2 \pm 0.6$ & $\mathrm{n} / \mathrm{d}$ & $50.2 \pm 1.2$ \\
\hline 5 & 17,70 & $\begin{array}{l}\text { acid (recalculated } \\
\text { to L-Glutamic acid) }\end{array}$ & $\mathrm{n} / \mathrm{d}$ & $255.6 \pm 7.2$ & $728.8 \pm 29.6$ & $\mathrm{n} / \mathrm{d}$ & $\mathrm{n} / \mathrm{d}$ & $\mathrm{n} / \mathrm{d}$ & $\mathrm{n} / \mathrm{d}$ & $\mathrm{n} / \mathrm{d}$ & $\mathrm{n} / \mathrm{d}$ \\
\hline 6 & 17,81 & $\begin{array}{l}\text { L-Proline } \\
\text { L-Pyroglutamic }\end{array}$ & $\mathrm{n} / \mathrm{d}$ & $73.8 \pm 1.9$ & $4683.5 \pm 171.0$ & $\mathrm{n} / \mathrm{d}$ & $\mathrm{n} / \mathrm{d}$ & $2251.6 \pm 82.5$ & $49.6 \pm 1.8$ & $\mathrm{n} / \mathrm{d}$ & $68.8 \pm 2.4$ \\
\hline 7 & 19,84 & $\begin{array}{l}\text { acid (recalculated } \\
\text { to } \mathrm{L} \text {-Glutamic acid) }\end{array}$ & $1695.2 \pm 46.1$ & $8538.8 \pm 196.4$ & $12347.5 \pm 517.3$ & $1158.4 \pm 29.7$ & $\mathrm{n} / \mathrm{d}$ & $6318.5 \pm 295.1$ & $330.9 \pm 6.4$ & $1340.1 \pm 56.7$ & $783.9 \pm 19.3$ \\
\hline 8 & 19,80 & L-Methionine & $\mathrm{n} / \mathrm{d}$ & $\mathrm{n} / \mathrm{d}$ & $\mathrm{n} / \mathrm{d}$ & $\mathrm{n} / \mathrm{d}$ & $84.1 \pm 2.4$ & $\mathrm{n} / \mathrm{d}$ & $\mathrm{n} / \mathrm{d}$ & $\mathrm{n} / \mathrm{d}$ & $\mathrm{n} / \mathrm{d}$ \\
\hline 9 & 20,24 & L-Serine & $\mathrm{n} / \mathrm{d}$ & $348.6 \pm 3.7$ & $790.6 \pm 25.3$ & $77.5 \pm 1.7$ & $14.2 \pm 0.2$ & $213.6 \pm 8.6$ & $\mathrm{n} / \mathrm{d}$ & $\mathrm{n} / \mathrm{d}$ & $24.2 \pm 0.8$ \\
\hline 10 & 20,57 & L-Threonine & $\mathrm{n} / \mathrm{d}$ & $473.8 \pm 9.6$ & $1645.5 \pm 27.5$ & $63.9 \pm 1.3$ & $\mathrm{n} / \mathrm{d}$ & $190.1 \pm 5.4$ & $\mathrm{n} / \mathrm{d}$ & $\mathrm{n} / \mathrm{d}$ & $\mathrm{n} / \mathrm{d}$ \\
\hline 11 & 21,25 & L-Phenylalanine & $\mathrm{n} / \mathrm{d}$ & $391.0 \pm 9.1$ & $\mathrm{n} / \mathrm{d}$ & $\mathrm{n} / \mathrm{d}$ & $\mathrm{n} / \mathrm{d}$ & $68.4 \pm 2.3$ & $\mathrm{n} / \mathrm{d}$ & $\mathrm{n} / \mathrm{d}$ & $\mathrm{n} / \mathrm{d}$ \\
\hline 12 & 21,86 & L-Aspartic acid & $\mathrm{n} / \mathrm{d}$ & $63.1 \pm 1.5$ & $355.9 \pm 9.7$ & $\mathrm{n} / \mathrm{d}$ & $\mathrm{n} / \mathrm{d}$ & $\mathrm{n} / \mathrm{d}$ & $\mathrm{n} / \mathrm{d}$ & $\mathrm{n} / \mathrm{d}$ & $31.4 \pm 0.7$ \\
\hline 13 & 22,95 & L-Glutamic acid & $\mathrm{n} / \mathrm{d}$ & $\mathrm{n} / \mathrm{d}$ & $381.8 \pm 9.9$ & $\mathrm{n} / \mathrm{d}$ & $\mathrm{n} / \mathrm{d}$ & $\mathrm{n} / \mathrm{d}$ & $\mathrm{n} / \mathrm{d}$ & $\mathrm{n} / \mathrm{d}$ & $\mathrm{n} / \mathrm{d}$ \\
\hline 14 & 23,91 & L-Lysine & $\mathrm{n} / \mathrm{d}$ & $\mathrm{n} / \mathrm{d}$ & $150.5 \pm 40.9$ & $\mathrm{n} / \mathrm{d}$ & $\mathrm{n} / \mathrm{d}$ & $\mathrm{n} / \mathrm{d}$ & $\mathrm{n} / \mathrm{d}$ & $\mathrm{n} / \mathrm{d}$ & $\mathrm{n} / \mathrm{d}$ \\
\hline 15 & 26,08 & L-Tyrosine & $\mathrm{n} / \mathrm{d}$ & $\mathrm{n} / \mathrm{d}$ & $452.7 \pm 16.2$ & $\mathrm{n} / \mathrm{d}$ & $326.6 \pm 6.9$ & $\mathrm{n} / \mathrm{d}$ & $\mathrm{n} / \mathrm{d}$ & $\mathrm{n} / \mathrm{d}$ & $\mathrm{n} / \mathrm{d}$ \\
\hline & & Total amount & 1757.1 & 14653.2 & 31993.3 & 1735.8 & 484.9 & 9960.5 & 488.3 & 1340.1 & 1154.6 \\
\hline
\end{tabular}

$\mathrm{n} / \mathrm{d}$ : not detected. 


\section{Results}

\subsection{Amino Acids Analysis}

The GC-MS chromatograms of the test solutions established the presence of 13 amino acids and 2 additional amino acids (4-aminobutanoic and pyroglutamic acids), which were re-calculated on L-glutamic acid. Amino acids in Iridaceae plants dry extracts were identified by comparing the retention times of selected amino acids in specific MS chromatograms. Quantitative analysis was performed using calibration curves build with standards solutions. Concentration range of standards was from 0.1 to $100 \mathrm{ng} / \mathrm{mL}$.

The elution order of amino acids standards is presented in Figure 1: alanine, valine, leucine, isoleucine, proline, metionine, serine, threonine, phenylalanine, aspartic acid, glutamic acid, lysine, tyrosine. The standards have been extracted and derivatized as previously described in the sample preparation session. Precision gave a lower value than RSD $=2 \%$, except Arg, Cys and Tyr and sensitivity value lower than $10 \mathrm{ng}$ of all amino acids injected. All standards samples followed the same extraction and derivatization steps. Additionally, two amino acids, viz. 4-aminobutanoic and L-pyroglutamic acids, were calculated via L-glutamic acid. The quantitative content of identified amino acids is presented in Table 1.

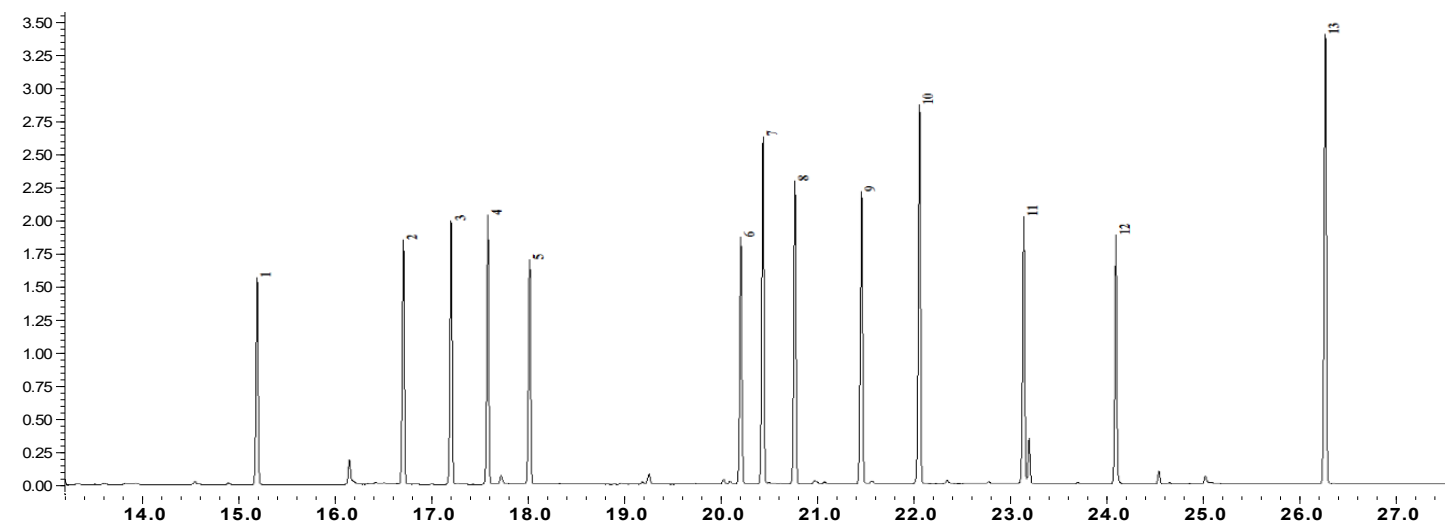

Figure 1. GC-MS chromatogram of amino acid standards mixture: 1) L-Alanine; 2) L-Valine; 3) L-Leucine; 4) Isoleucine; 5) L-Proline; 6) L-Methionine; 7) L-Serine; 8) L-Threonine; 9) L-Phenylalanine; 10) L-Aspartic acid; 11) L-Glutamic acid; 12) L-Lysine; 13) L-Tyrosine.

\subsection{Method Validation}

To validate the results obtained in our study, precision, repeatability, limit of detection (LOD), limit of quantification (LOQ), and linearity were calculated according to the International Conference for Harmonization (hereafter, ICH) [44]. The data obtained are presented in Tables 2-4. The method was validated using amino acid standards. The limit of detection (LOD) (signal/noise $=3$ ) and the limit of quantification $(\mathrm{LOQ})($ signal/noise $=10$ ) of all compounds varied within the range $0.14-0.72 \mathrm{ng} / \mathrm{mL}$ and $0.2-2.4 \mathrm{ng} / \mathrm{mL}$ respectively. The precision of the method was evaluated by measuring the peak chromatographic area of amino acids six times on the same test sample. The precision of retention times and peak areas of mixing amino acids standards for the replicated injection were in the range of $0.70-1.92 \%$ of RSD $(n=6)$. The reproducibility and repeatability of the method were evaluated by analysing six injections of the sample solution and two replicates of herbal sample extraction, respectively. To confirm the accuracy of the method, a recovery experiment was performed by mixed quantified samples with specific quantities of reference compounds. The average percentages of recovery of mixed amino acids standards ranged from $81.92 \%$ to $113.00 \%$. The results demonstrated that conditions for the amino acids analysis were repeatable and accurate. 
Table 2. Regression parameter, linearity, limit of detection (LOD) and limit of quantification (LOQ) of the proposed GC-MS method.

\begin{tabular}{|c|c|c|c|c|c|}
\hline Amino Acid & Calibration Curve & $\begin{array}{l}\text { Correlation } \\
\text { coefficient } r^{2}\end{array}$ & $\begin{array}{l}\text { Linear Range } \\
(\mu \mathrm{m} / \mathrm{mL})\end{array}$ & $\begin{array}{c}\text { LOD } \\
(\mathrm{ng} / \mathrm{mL})\end{array}$ & $\begin{array}{c}\text { LOQ } \\
(\mathrm{ng} / \mathrm{mL})\end{array}$ \\
\hline L-Alanine & $\begin{array}{c}f(x)=276580.863935 \times \\
x-353207.105647\end{array}$ & 0.983122 & $11.15-44.6$ & 0.72 & 2.4 \\
\hline L-Valine & $\begin{array}{c}f(x)=243032.088633 \times \\
x+49012.859468\end{array}$ & 0.975345 & $14.7-58.8$ & 0.585 & 1.930 \\
\hline L-Leucine & $\begin{array}{c}f(x)=277306.790190 \times \\
x-217513.405090\end{array}$ & 0.963603 & $16.5-58.8$ & 0.1257 & 0.459 \\
\hline Isoleucine & $\begin{array}{c}f(x)=228260.308590 \times \\
x+246041.176091\end{array}$ & 0.969531 & $16.45-65.8$ & 0.125 & 0.491 \\
\hline L-Proline & $\begin{array}{c}f(x)=280385.380976 \times \\
x+1325395.667639\end{array}$ & 0.972168 & $14.4-57.6$ & 0.247 & 0.970 \\
\hline L-Methionine & $\begin{array}{c}f(x)=187897.462370 \times \\
x-557659.056929\end{array}$ & 0.981929 & $18.65-74.6$ & 0.184 & 0.213 \\
\hline L-Serine & $\begin{array}{c}f(x)=317111.017808 \times \\
x+1640589.305389\end{array}$ & 0.957872 & $13.15-52.6$ & 0.14 & 0.470 \\
\hline L-Threonine & $\begin{array}{c}f(x)=249467.821934 \times \\
x+2284199.418438\end{array}$ & 0.953095 & $14.9-59.6$ & 0.132 & 0.44 \\
\hline L-Phenylalanine & $\begin{array}{c}f(x)=206843.387916 \times \\
x+74215.145383\end{array}$ & 0.963723 & $20.65-82.6$ & 0.375 & 0.482 \\
\hline L-Aspartic acid & $\begin{array}{c}f(x)=267570.147433 \times \\
x+2368216.421104\end{array}$ & 0.942835 & $16.65-66.6$ & 0.308 & 0.362 \\
\hline $\begin{array}{l}\text { L-Glutamic } \\
\text { acid }\end{array}$ & $\begin{array}{c}f(x)=214747.719667 \times \\
x-596641.230769\end{array}$ & 0.980993 & $18.4-73.6$ & 0.195 & 0.651 \\
\hline L-Lysine & $\begin{array}{c}f(x)=232710.756329 \times \\
x-3270542.068621\end{array}$ & 0.988024 & $18.25-73.00$ & 0.34 & 0.144 \\
\hline L-Tyrosine & $\begin{array}{c}f(x)=213345.354626 \times \\
x+3840401.269116\end{array}$ & 0.885138 & $22.65-90.6$ & 0.53 & 1.76 \\
\hline
\end{tabular}

Table 3. Precision and repeatability of GC-MS method.

\begin{tabular}{cccc}
\hline \multirow{2}{*}{ Amino Acid } & RSD of Retention Time (\%) & Precision & Repeatability \\
\cline { 3 - 4 } & & RSD of Area (\%) & RSD of Area (\%) \\
\hline L-Alanine & 0.01 & 1.52 & 0.75 \\
L-Valine & 0.009 & 1.34 & 1.64 \\
L-Leucine & 0.01 & 1.78 & 1.70 \\
Isoleucine & 0.008 & 1.80 & 0.83 \\
4-Aminobutanoic acid & 0.01 & 1.92 & 1.73 \\
L-Proline & 0.01 & 0.78 & 0.95 \\
L-Pyroglutamic acid & 0.1 & 1.71 & 0.94 \\
L-Methionine & 0.008 & 1.53 & 1.72 \\
L-Serine & 0.008 & 1.94 & 0.62 \\
L-Threonine & 0.01 & 0.83 & 1.48 \\
L-Phenylalanine & 0.009 & 1.71 & 0.72 \\
L-Aspartic acid & 0.01 & 2.39 & 1.37 \\
L-Glutamic acid & 0.009 & 1.56 & 1.41 \\
L-Lysine & 0.01 & 0.70 & 0.67 \\
L-Tyrosine & 0.04 & 1.75 & 0.88 \\
\hline
\end{tabular}


Table 4. Accuracy of GC-MS method.

\begin{tabular}{|c|c|c|c|c|c|c|c|}
\hline Amino Acid & $\begin{array}{l}\text { Found } \\
(\mu \mathrm{g} / \mathrm{mL})\end{array}$ & $\begin{array}{c}\text { Added } \\
(\mu \mathrm{g} / \mathrm{mL})\end{array}$ & $\begin{array}{c}\text { Recovery } \\
(\%)\end{array}$ & Amino Acid & $\begin{array}{l}\text { Found } \\
(\mu \mathrm{g} / \mathrm{mL})\end{array}$ & $\begin{array}{c}\text { Added } \\
(\mu \mathrm{g} / \mathrm{mL})\end{array}$ & $\begin{array}{c}\text { Recovery } \\
(\%)\end{array}$ \\
\hline \multirow{3}{*}{ L-Alanine } & 10.69 & 11.15 & 95.86 & \multirow{3}{*}{ L-Threonine } & 14.88 & 14.90 & 99.87 \\
\hline & 19.40 & 22.30 & 86.99 & & 30.51 & 37.25 & 81.91 \\
\hline & 34.16 & 33.45 & 102.11 & & 50.51 & 44.70 & 113.00 \\
\hline \multirow{3}{*}{ L-Valine } & 13.98 & 14.70 & 95.11 & \multirow{3}{*}{ L-Phenylalanine } & 18.16 & 20.65 & 87.92 \\
\hline & 25.66 & 29.40 & 87.27 & & 35.63 & 41.30 & 86.27 \\
\hline & 46.95 & 44.10 & 106.46 & & 68.05 & 61.95 & 109.85 \\
\hline \multirow{3}{*}{ L-Leucine } & 15.96 & 16.50 & 96.74 & \multirow{3}{*}{ L-Aspartic acid } & 14.58 & 16.65 & 87.56 \\
\hline & 27.15 & 33.10 & 82.01 & & 34.77 & 33.30 & 104.42 \\
\hline & 48.91 & 44.10 & 110.91 & & 56.61 & 49.95 & 113.34 \\
\hline \multirow{3}{*}{ Isoleucine } & 16.05 & 16.45 & 97.57 & \multirow{3}{*}{ L-Glutamic acid } & 15.66 & 18.40 & 85.11 \\
\hline & 28.17 & 32.90 & 85.63 & & 31.65 & 36.80 & 86.02 \\
\hline & 54.87 & 49.35 & 111.18 & & 57.23 & 55.20 & 103.67 \\
\hline \multirow{3}{*}{ L-Proline } & 13.79 & 14.40 & 95.73 & \multirow{3}{*}{ L-Lysine } & 16.39 & 18.25 & 89.82 \\
\hline & 28.20 & 28.80 & 97.92 & & 25.93 & 27.38 & 94.72 \\
\hline & 48.28 & 43.20 & 111.75 & & 51.51 & 54.75 & 94.08 \\
\hline \multirow{3}{*}{ L-Methionine } & 16.58 & 18.65 & 88.89 & \multirow{3}{*}{ L-Tyrosine } & 18.67 & 22.65 & 82.43 \\
\hline & 31.86 & 37.30 & 85.41 & & 49.89 & 45.30 & 110.13 \\
\hline & 57.05 & 55.95 & 101.97 & & 79.25 & 67.95 & 116.62 \\
\hline \multirow{3}{*}{ L-Serine } & 11.93 & 13.15 & 90.73 & & & & \\
\hline & 26.30 & 26.30 & 100.00 & & & & \\
\hline & 44.53 & 39.45 & 112.89 & & & & \\
\hline
\end{tabular}

\section{Discussion}

Due to the polar nature of amino acids, derivatization is required prior to GC analysis [45]. A higher sensitivity can be reached during the analysis of amino acids for GC-MS by using derivatization agents, such as N-tert-butyldimethylsilyl- N-methyltrifluoroacetamide (MTBSTFA) and $\mathrm{N}, \mathrm{O}-\mathrm{bis}$ (trimethylsilyl)trifluoroacetamide (BSTFA). Although, MTBSTFA derivatives are more stable and contain less moisture.

Previous good results using the MTBSTFA reagent was the reason for its use in our investigation. The suitability of this method-both for the identification and the quantification of amino acids in samples-was demonstrated by the good resolution (Figure 1) and validation results data (Tables 2-4).

Experimental data showed that the Crocus and Juno leaves extracts are characterized by the highest general content of amino acids- $31.99 \mathrm{mg} / \mathrm{g}$ and $14.65 \mathrm{mg} / \mathrm{g}$, respectively, compared with other Iridaceae dry extracts. The results of free amino acid content in Iridaceae extracts are shown in Table 1.

According to a comparative analysis of the composition of amino acids in examined Iridaceae extract plants parts, it can be seen that the aboveground organs (leaves, flowers, stigma) have a higher content and a diverse composition of amino acids than their underground organs (corms and rhizomes). The largest number of amino acids with high abundance were detected in the Crocus leaves extract (Figure 2a) and in Juno leaves dry extract (Figure 2b). Common among them were alanine, valine, leucine, isoleucine, proline, serine, threonine, aspartic acid, 4-aminobutanoic acid, and pyroglutamic acid. Additionally, the extracts of Crocus leaves contained glutamic acid, lysine, tyrosine. A significantly less amount and content of amino acids were found in Gladiolus leaves, Crocus flowers and Crocus stigma extracts. Crocus corms were found to have the highest amino acid concentration compared to the other underground organ extracts. The similar determination of free amino acids in the methanol extracts of Acacia and Eucalyptus leaves by GC-MS method with TBDMS derivatives [46] demonstrated that only a few free amino acids were identified including proline, methionine, phenylalanine, cysteine, and lysine. By the other investigation [47], arginine, leucine and glutamic acid in tubers and leaves of Coccinia abyssinica had the highest content among all amino acids. Besides, the average amino acid content was higher in the leaves compared to the tubers, that is 
corresponding to the current investigation of Iridaceae plant extracts. Thus, studies are shown that the number of identified free amino acids in plant extracts is not high.

a
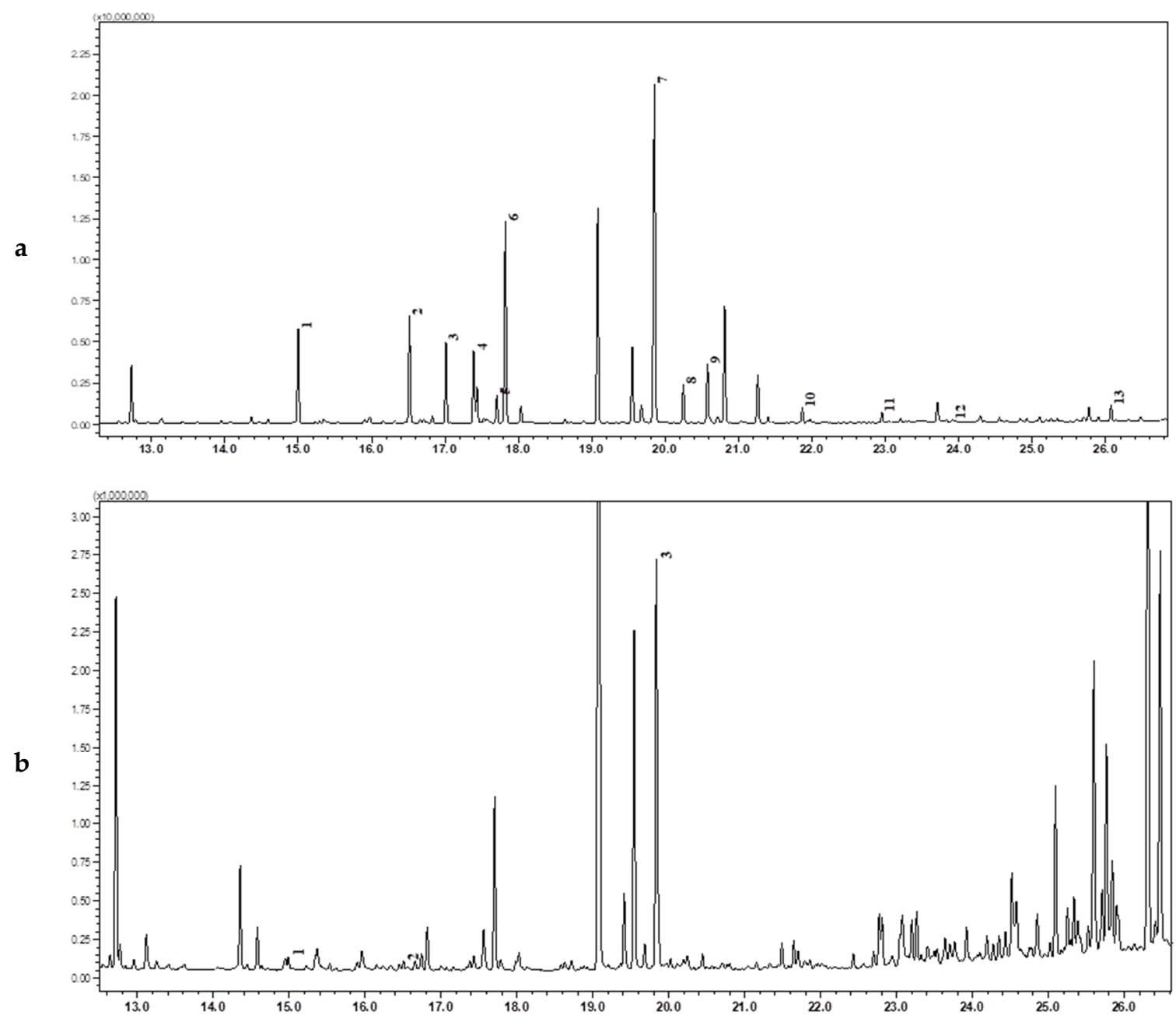

Figure 2. GC-MS chromatograms for the analysis of amino acid Crocus leaves (a) and Gladiolus leaves (b) dry extracts: 1) L-Alanine; 2) L-Valine; 3) L-Leucine; 4) Isoleucine; 5) L-Proline; 6) L-Methionine; 7) L-Serine; 8) L-Threonine; 9) L-Phenylalanine; 10) L-Aspartic acid; 11) L-Glutamic acid; 12) L-Lysine; 13) L-Tyrosine.

In Iris hungarica rhizomes, this method was able to identify only one pyroglutamic acid $(1.34 \mathrm{mg} / \mathrm{g})$, as well as in Iris variegata rhizomes extract alanine, valine, isoleucine, proline, serine, aspartic acid and also pyroglutamic acid were found. Corms extracts, viz. Crocus and Juno have five common amino acids; among them, pyroglutamic acid $(6.32 \mathrm{mg} / \mathrm{g}$ and $0.33 \mathrm{mg}$, respectively) and proline $(2.25 \mathrm{mg} / \mathrm{g}$ and $0.05 \mathrm{mg} / \mathrm{g}$, respectively) were dominant.

The aboveground organs of Iridaceae were also characterized by a high content of pyroglutamic acid, from $1.16 \mathrm{mg} / \mathrm{g}$ for Crocus flower and up to $12.35 \mathrm{mg} / \mathrm{g}$ for Crocus leaves. The group of aliphatic amino acids such as alanine ( 0.03 to $2.71 \mathrm{mg} / \mathrm{g})$, valine $(0.02$ to $3.02 \mathrm{mg} / \mathrm{g})$, leucine $(0.07$ to $2.40 \mathrm{mg} / \mathrm{g})$, and isoleucine ( 0.1 to $2.32 \mathrm{mg} / \mathrm{g}$ ) were also found to be the highest compared to the other amino acids in samples.

The content of free amino acids for $C$. sativus extracts decreases at leaves $>$ corms $>$ flowers $>$ stigmas. The results show that the dry aqueous extract of Crocus leaves has the highest concentration of certain free amino acids, which possibly explains [48] the presence of a pronounced antioxidant effect in leaves $[17,21,22]$. The predominant amino acids Crocus leaves extract were of the hydrophobic amino acids group (alanine $(2.71 \mathrm{mg} / \mathrm{g})$, valine $(3.02 \mathrm{mg} / \mathrm{g})$, leucine $(2.40 \mathrm{mg} / \mathrm{g})$, isoleucine $(2.32 \mathrm{mg} / \mathrm{g})$, proline 
$(4.68 \mathrm{mg} / \mathrm{g}))$, which, according to the authors of [49], can inhibit free radicals by proton donation [50] and exhibited a high antioxidant activity in plant extracts. Among the investigated samples, the dry extract of Crocus leaves was characterized by the highest content of pyroglutamic acid $(12.35 \mathrm{mg} / \mathrm{g})$. The content of pyroglutamic acid in the Crocus raw material can be placed in the following order: leaves $(12.35 \mathrm{mg} / \mathrm{g})>$ corm $(6.32 \mathrm{mg} / \mathrm{g})>$ flower $(1.16 \mathrm{mg} / \mathrm{g})$. Besides this, the presence of glutamine acid $(0.38 \mathrm{mg} / \mathrm{g})$ and the essential amino acid lysine $(0.15 \mathrm{mg} / \mathrm{g})$ were found only in Crocus leaves extract. In the stigma extract only alanine, serine and tyrosine have been detected, as well as methionine $(0.08 \mathrm{mg} / \mathrm{g})$, which was found only in this sample. An analysis [51] of the free amino acids composition of 20 Crocus stigma from different countries (Spain, Italy, Greece, Iran) showed that alanine, proline and aspartic acid were the major amino acids in all tested samples. The differences in the obtained results can be explained by the environmental factors, that affect the plant chemical composition [52-55]. In Crocus stigma and leaves extracts tyrosine was also found $(0.32 \mathrm{mg} / \mathrm{g}$ and $0.45 \mathrm{mg} / \mathrm{g}$, respectively), which is absent in other Iridaceae extracts. Phenylalanine has been found only in Crocus corms and in small amounts $(0.06 \mathrm{mg} / \mathrm{g})$.

The Juno leaves extract has a more diverse amino acid composition compared to Juno corms. The content of all identified amino acids in Juno the corms extract is much less than in its leaves. 4-Aminobutanoic acid $(0.25 \mathrm{mg} / \mathrm{g})$ was identified in Juno leaves like in Crocus leaves $(0.72 \mathrm{mg} / \mathrm{g})$. Serine $(0.34 \mathrm{mg} / \mathrm{g})$, threonine $(0.47 \mathrm{mg} / \mathrm{g})$ and phenylalanine $(0.39 \mathrm{mg} / \mathrm{g})$ has been found only in Juno leaves as in Crocus corms. Among the hydrophobic amino acids in Juno leaves extract were alanine $(1.03 \mathrm{mg} / \mathrm{g})$, valine $(1.41 \mathrm{mg} / \mathrm{g})$, leucine $(1.01 \mathrm{mg} / \mathrm{g})$, isoleucine1.04 $\mathrm{mg} / \mathrm{g})$, proline $(0.07 \mathrm{mg} / \mathrm{g})$, and phenylalanine $(0.39 \mathrm{mg} / \mathrm{g})$.

In Gladiolus leaves, alanine $(0.03 \mathrm{mg} / \mathrm{g})$, valine $(0.02 \mathrm{mg} / \mathrm{g})$ and pyroglutamic acid $(1.69 \mathrm{mg} / \mathrm{g})$ were found in lower concentrations compared other extracts.

The major free amino acids in Iridaceae extracts were pyroglutamic acid (with the ranges of $0.3-12.35 \mathrm{mg} / \mathrm{g}$ ), proline (with the ranges of $0.05-4.68 \mathrm{mg} / \mathrm{g}$ ) and valine (with the ranges of $0.02-3.02 \mathrm{mg} / \mathrm{g}$ ). Pyroglutamic acid has been described as the major amino acid in all extracts. According to authors $[27,28] \gamma$-glutamyl peptides are very common in Iridaceae plants.

The high content of pyroglutamic and aspartic acids in samples can be explained by the relationship between the primary and secondary metabolism of amino acids in plants, since glutamic acid is a precursor in the biosynthesis of all amino acids in plant parts [56,57]. Aspartic acid is synthesized by direct amination, and alanine and glutamic acid are formed as a result of reductive amination. All other amino acids are secondary ones, because they are formed as a result of the transamination of the amino acids listed above with the corresponding keto acids that arise during the metabolism, as well as by the conversion of some acids to others [58]. The dehydration of glutamic acid leads to the formation of its lactam-pyroglutamic acid, which is the key precursor in the biosynthesis of biologically active compounds of primary and secondary metabolites [59].

It should be noted that pyroglutamic acid plays a great role as a mediator of the central nervous system [58]. Thus, in the future, it would be advisable to pay attention to the examination of Crocus and Juno leaves extracts as possible CNS-agents. In addition, it should be noted that the content of essential amino acids [60] is high enough for the extracts of Crocus and Juno leaves. The highest content of valine $(1.41-3.02 \mathrm{mg} / \mathrm{g})$, leucine $(1.01-2.40 \mathrm{mg} / \mathrm{g})$, isoleucine $(1.04-2.32 \mathrm{mg} / \mathrm{g})$ and threonine $(0.47-1.64 \mathrm{mg} / \mathrm{g})$ for extracts were established. Methionine $(0.08 \mathrm{mg} / \mathrm{g})$ was identified only in the Crocus stigma extract, while lysine $(0.15 \mathrm{mg} / \mathrm{g})$ only in Crocus leaves extract. The content of essential amino acids also could be taken into account in future pharmacological studies.

As a result of this work, the comparative analyses of amino acids in the aqueous dry extracts of Crocus sativus (stigma, flowers, leaves, corms), Juno bucharica (leaves, corms), Gladiolus hybrid Zefir (leaves) and Iris hungarica (rhizomes), Iris variegata (rhizomes) from Ukrainian flora using a simple and sensitive gas chromatography method were carried out for the first time. It should be noted that the amino acid content in extracts from the aboveground organs (leaves, flowers, stigma) is much higher compared to their underground organs (corms and rhizomes). Pyroglutamic acid—as 
well as valine, alanine, proline, valine, leucine, and isoleucine-predominate in all studied extracts. Due to the fact that amino acids take part in various metabolic processes and their role in pathological correction, it is important to learn about the pharmacological activities of investigated Iridaceae plants from Ukrainian flora. Attention should be paid to future pharmacological studies on the nootropic and moderate excitatory activities of the plant extracts examined. Furthermore, the predominant hydrophobic amino acid group (alanine, valine, leucine, isoleucine, proline, and phenylalanine) in the extracts is an important factor, that affects the antioxidant properties of plants.

Author Contributions: Conceptualization was done by O.M. and V.G.; Methodology and experimental works were done by O.M., I.B. and L.I.; Data Analysis was done by L.I., O.M. and R.L.; writing, review and editing the paper were done by O.M., I.B. and V.G., Project administration and supervision were done by R.L. and V.G. All authors have read and agreed to the published version of the manuscript.

Funding: This research received no external funding.

Conflicts of Interest: The authors declare no conflict of interest.

\section{References}

1. Capasso, F.; Gaginella, T.S.; Grandolini, G.; Izzo, A.A. (Eds.) Phytotherapy: A Quick Reference to Herbal Medicine; Springer: Berlin/Heidelberg, Germany; New York, NY, USA, 2003; 500p. [CrossRef]

2. Essafi, H.; Trambelsi, N.; Benincasa, C.; Tamaalli, A.; Perri, E.; Zarrouk, M. Phytochemical profile, antioxidant and antiproliferative activities of olive leaf extracts from autochthonous Tunisian cultivars. Acta Aliment. 2019, 48, 384-390. [CrossRef]

3. Essafi, H.; Trambelsi, N.; Chimento, A.; Benincasa, C.; Tamaalli, A.; Perri, E.; Zarrouk, M.; Pezzi, V. Olea europaea L. Flowers as a new promising anticancer natural product: Phenolic composition, antiproliferative activity and apoptosis induction. Nat. Prod. Res. 2019, 1-4. [CrossRef] [PubMed]

4. Anjum, S.; Ahmed Bazai, Z.; Rizwan, S.; Benincasa, C.; Mehmood, K.; Siddique, N.; Shaheen, G.; Mehmood, Z.; Azam, M.; Sajjad, A. Elemental characterization of medicinal plants and soils from Hazarganji Chiltan National Park and nearby unprotected areas of Balochistan, Pakistan. J. Oleo Sci. 2019, 68, 443-461. [CrossRef] [PubMed]

5. Niu, B.; Zheng, F.; Xu, J. Protective effect of gui zhi (Ramulus Cinnamomi) on abnormal levels of four amino acid neurotransmitters by chronically ma huang (Herb Ephedra) intoxicated prefrontal cortex in rats treated with a ma huang-gui zhi herb pair. J. Ethnopharmacol. 2019, in press. [CrossRef] [PubMed]

6. He, Q.; Huang, S.; Wu, Y.; Zhang, W.; Wang, F.; Cao, J.; Sheng, Q.; Liang, Z.; Liu, L.; Ou, W.B. Comparative study on the composition of free amino acids and derivatives in the two botanical origins of an edible Chinese herb "Xiebai", i.e., Allium chinense G. Don and Allium macrostemon Bunge species. Food Res. Int. 2018, 106, 446-457. [CrossRef]

7. Firenzuoli, F.; Gori, L. Herbal medicine today: Clinical and research issues. Evid. Based Complement. Altern. Med. 2007, 4, 37-40. [CrossRef]

8. Papes, F.; Surpili, M.J.; Langone, F.; Trigo, J.R.; Arruda, P. The essential amino acid lysine acts as precursor of glutamate in the mammalian central nervous system. FEBS Lett. 2001, 488, 34-38. [CrossRef]

9. Musgrave, T.; Tenorio, G.; Rauw, G.; Baker, G.B.; Kerr, B.J. Tissue concentration changes of amino acids and biogenic amines in the central nervous system of mice with experimental autoimmune encephalomyelitis (EAE). Neurochem. Int. 2011, 59, 28-38. [CrossRef]

10. Singab, A.N.B.; Ayoub, I.M.; El-Shazly, M.; Korinek, M.; Wu, T.Y.; Cheng, Y.B.; Wu, Y.C. Shedding the light on Iridaceae: Ethnobotany, phytochemistry and biological activity. Ind. Crop. Prod. 2016, 92, 308-335. [CrossRef]

11. Mykhailenko, O.; Kovalyov, V.; Goryacha, O.; Ivanauskas, L.; Georgiyants, V. Biologically active compounds and pharmacological activities of species of the genus Crocus: A review. Phytochemistry 2019, 162, 56-89. [CrossRef]

12. Gohari, A.R.; Saeidnia, S.; Mahmoodabadi, M.K. An overview on saffron, phytochemicals, and medicinal properties. Pharmacogn. Rev. 2013, 7, 61-66. [CrossRef] [PubMed] 
13. Xie, G.Y.; Zhu, Y.; Shu, P.; Qin, X.Y.; Wu, G.; Wang, Q.; Qin, M.J. Phenolic metabolite profiles and antioxidants assay of three Iridaceae medicinal plants for traditional Chinese medicine "She-gan" by on-line HPLC-DAD coupled with chemiluminescence (CL) and ESI-Q-TOF-MS/MS. J. Pharm. Biomed. Anal. 2014, 98, 40-51. [CrossRef] [PubMed]

14. Kostić, A.Ž.; Gašić, U.M.; Pešić, M.B.; Stanojević, S.P.; Barać, M.B.; Mačukanović-Jocić, M.P.; Avramov, S.N.; Tešić, Ž.L. Phytochemical analysis and total antioxidant capacity of rhizome, above-ground vegetative parts and flower of three Iris species. Chem. Biodivers. 2019, 16, e1800565. [CrossRef] [PubMed]

15. Mykhailenko, O.; Kovalyov, V.; Kovalyov, S.; Toryanik, E.; Osolodchenko, T.; Buidin, Y. Fatty acid composition of lipids of Iris sibirica. Cesk. Sloven. Farm. 2017, 66, 220-227.

16. Munyemana, F.; Mondego, A.P.; Cumbane, P. Qualitative Phytochemical Screening and Antimicrobial Activity Evaluation of the Bulb Extracts of Gladiolus Psittacinus Hook (Iridaceae); International Network Environmental Management Conflicts: Santa Catarina, Brazil, 2013; Volume 2, pp. 14-31.

17. Jadouali, S.M.; Rachid, H.A.; Majourhat, M.K.; Abdelatif, Z.B.; Faouzi, L.A. Chemical characterization and antioxidant compounds of flower parts of Moroccan Crocus sativus L. J. Saudi Soc. Agric. Sci. 2019, 18, 476-480. [CrossRef]

18. Basgedik, B.; Ugurb, A.; Sarac, N. Antimicrobial, antioxidant, and antimutagenic activities of Gladiolus illyricus. J. Pharm. Pharmacogn. Res. 2014, 2, 93-99.

19. Wollenweber, E.; Stevens, J.F.; Klimo, K.; Knauft, J.; Frank, N.; Gerhauser, C. Cancer chemopreventive in vitro activities of isoflavones isolated from Iris germanica. Planta Med. 2003, 69, 15-20. [CrossRef]

20. Shinwari, K.J.; Rao, P.S. Thermal-assisted high hydrostatic pressure extraction of nutraceuticals from saffron (Crocus sativus): Process optimization and cytotoxicity evaluation against cancer cells. Innov. Food Sci. Emerg. Technol. 2018, 48, 296-303. [CrossRef]

21. Chen, Y.; Zhang, H.; Tian, X.; Zhao, C.; Cai, L.; Liu, Y.; Jia, L.; Yin, H.X.; Chen, H.X. Antioxidant potential of crocins and ethanol exracts of Gardenia jasminoides ELLIS and Crocus sativus L.: A relationahip investigation between antioxidant activity and crocin content. Food Chem. 2008, 109, 484-492. [CrossRef]

22. Montoro, P.; Maldini, M.; Luciani, L.; Tuberoso, C.I.G.; Congiu, F.; Pizza, C. Radical scavenging activity and LC-MS metabolic profiling of petals, stamens, and flowers of Crocus sativus L. J. Food Sci. 2012, 77, 893-900. [CrossRef]

23. Huwaitat, S.; Al-Khateeb, E.; Finjan, S.; Maraqa, A. Antioxidant and antimicrobial activities of Iris nigricans methanolic extracts containing phenolic compounds. Eur. Sci. J. 2013, 9, 83-91.

24. Korinek, M.; Mykhailenko, O.; Hsieh, C.F.; Georgiyants, V.; El-Shazly, M.; Handoussa, H.; Horng, J.T.; Hwang, T.L. Antiviral effects of herbs from Ukraine against influenza and enterovirus. In Proceedings of the 34th Symposium of Natural Products, Taoyuan, Taiwan, 17-19 October 2019.

25. Alam, A.; Jaiswal, V.; Akhtar, S.; Jayashree, B.S.; Dhar, K.L. Isolation of isoflavones from Iris kashmiriana Baker as potential anti proliferative agents targeting NF-kappaB. Phytochemistry 2017, 136, 70-80. [CrossRef] [PubMed]

26. Lamshöft, M.; Marner, F.J. Analysis of the iridals in rhizome extracts of Iris variegata Linn. Nat. Prod. Res. 2005, 19, 57-60. [CrossRef]

27. Peder, O.; Larsena, M.; Sundahla, F.; Torben, S.; Wieczorkowskaa, E.; Goldblat, P. Relationship between subfamilies, tribes and genera in Iridaceae inferred from chemical characters. Biochem. Syst. Ecol. 1987, 15, 575-579. [CrossRef]

28. Peder, O.; Larsena, M.; Sundahla, F.; Torben, S.; Wieczorkowskaa, E.; Goldblat, P. Meta-carboxy-substituted aromatic amino acids and $\gamma$-glutamyl peptides: Chemical characters for classification in the Iridaceae. Biochem. Syst. Ecol. 1981, 9, 313-323. [CrossRef]

29. Chen, Y.; Fu, X.; Mei, X.; Zhou, Y.; Cheng, S.; Zeng, L.; Dong, F.; Yang, Z. Proteolysis of chloroplast proteins is responsible for accumulation of free amino acidsin dark-treated tea (Camellia sinensis) leaves. J. Proteom. 2017, 157, 10-17. [CrossRef]

30. Hung, Y.T.; Chen, P.C.; Chen, R.L.C.; Cheng, T.J. Sequential determination oftannin and total amino acid contents in tea for taste assessment by a fluorescent flow-injection analytical system. Food Chem. 2010, 118, 876-881. [CrossRef]

31. Zhu, Y.; Luo, Y.; Wang, P.; Zhao, M.; Li, L.; Hu, X.; Chen, F. Simultaneous determination of free amino acids in Pu-erh tea and their changes during fermentation. Food Chem. 2015, 194, 643-649. [CrossRef] 
32. Horanni, R.; Engelhardt, U.H. Determination of amino acids in white, green, black, oolong, puerh teas and tea products. J. Food Compos. Anal. 2013, 31, 94-100. [CrossRef]

33. Zhou, P.; Zhao, F. Determination of 21 free amino acids in 5 types of tea by ultra-high performance liquid chromatography coupled with tandem mass spectrometry (UHPLC-MS/MS) using a modified 6-aminoquinolyl-N-hydroxysuccinimidyl carbamate (AQC) method. J. Food Compos. Anal. 2019, 81, 46-54. [CrossRef]

34. Fu, G.; He, Y.; Wang, X.; Wang, L. Determination of amino acids in tea samples bycapillary electrophoresis with partition cell and indirect ultraviolet detection. Chin. J. Chromatogr. 2007, 25, 193-196.

35. Hener, C.; Hummel, S.; Suarez, J.; Stahl, M.; Kolukisaoglu, Ü. d-Amino acids are exuded by arabidopsis thaliana roots to the rhizosphere. Int. J. Mol. Sci. 2018, 19, 1109. [CrossRef]

36. Prokopenko, Y.; Jakštas, V.; Žvikas, V.; Georgiyants, V.; Ivanauskas, L. Hilic MS/MS determination of amino acids in herbs of Fumaria schleicheri L., Ocimum basilicum L., and leaves of Corylus avellana L. Nat.Prod. Res. 2018, 33, 1961-1963. [CrossRef]

37. Koek, M.M.; Jellema, R.H.; Van der Greef, J.; Tas, A.C.; Hankemeier, T. Quantitative metabolomics based on gaschromatography mass spectrometry: Status and perspectives. Metabolomics 2011, 7, 307-328. [CrossRef]

38. Bruheim, P.; Kvitvang, H.F.N.; Villas-Boas, S.G. Stable isotope coded derivatizing reagents as internal standardsin metabolite profiling. J. Chromatogr. A 2013, 1296, 196-203. [CrossRef]

39. Vielhauer, O.; Zakhartsev, M.; Horn, T.; Takors, R.; Reuss, M. Simplified absolute metabolite quantification by gaschromatography-isotope dilution mass spectrometry on the basisof commercially available source material. J. Chromatogr. B 2011, 879, 3859-3870. [CrossRef]

40. Villas-Boas, S.G.; Smart, K.F.; Sivakumaran, S.; Lane, G.A. Alkylation or silylation for analysis of amino and non-amino organic acids by GC-MS? Metabolites 2011, 1, 3-20. [CrossRef]

41. Tumanov, S.; Zubenko, Y.; Obolonkin, V.; Greenwood, D.R.; Shmanai, V.; Villas-Bôas, S.G. Calibration curve-free GC-MS method for quantification of amino and non-amino organic acids in biological samples. Metabolomics 2016, 12, 64. [CrossRef]

42. Hryzodub, O.I.; Leontyev, D.A.; Dmitriyeva, M.V.; Rudyk, Z.S.; Kotov, A.G.; Kotova, E.E.; Kishenets, N.V.; Klestova, Z.S.; Zhemerova, K.G.; Chekalova, S.O.; et al. State Pharmacopoeia of Ukraine: At 3 vol, 2nd ed.; State Enterprise "Ukrainian Scientific Pharmacopoeial Center of Medicines Quality": Kharkiv, Ukraine, 2015; Volume 1, p. 1128.

43. Council of Europe. European Pharmacopoeia, 9.2th ed.; Council of Europe: Strasbourg, France, 2017.

44. International Conference on Harmonization ( $\mathrm{ICH})$. Validation of Analytical Procedures: Text and Methodology Q2 (R1); ICH Secretariat: Geneva, Switzerland, 2005.

45. Jarukas, L.; Kamarauskaitė, J.; Marksa, M.; Trumbeckaitė, S.; Banienè, R.; Ivanauskas, L. Bio-based succinic acid sample preparation and derivatization procedure optimisation for gas chromatography-mass spectrometry analysis. Sci. J. Sci. Rise Pharm. Sci. 2018, 4, 9-13. [CrossRef]

46. Chen, Z.; Landman, P.; Colmer, T.D.; Adams, M.A. Simultaneous analysis of amino and organic acids in extracts of plant leaves astert-butyldimethylsilyl derivatives by capillary gas chromatography. Anal. Biochem. 1998, 259, 203-211. [CrossRef]

47. Ayalew, Y.; Retta, N.; Desse, G.; Mohammed, A.; Mellesse, A. Amino acid profile and protein quality in tuber and leaf of Coccnia abyssinica (Lam.) (Cogn.) accessions of Ethiopia. Food Sci. Nutr. 2016, 5, 722-729. [CrossRef] [PubMed]

48. Dash, P.; Ghosh, G. Amino acid composition, antioxidant and functional properties of protein hydrolysates from Cucurbitaceae seeds. J. Food Sci. Technol. 2017, 54, 4162-4172. [CrossRef] [PubMed]

49. Sonklin, C.; Laohakunjit, N.; Kerdchoechuen, O. Assessment of antioxidant properties of membrane ultrafiltration peptides from mungbean meal protein hydrolysates. Peer J. 2018, 6, e5337. [CrossRef] [PubMed]

50. Pompella, A.; Visvikis, A.; Paolicchi, A.; De Tata, V.; Casini, A.F. The changing faces of glutathione, a cellular protagonist. Biochem. Pharmacol. 2003, 66, 1499-1503. [CrossRef]

51. Del Campo, C.P.; Garde-Cerdán, T.; Sánchez, A.M.; Maggi, L.; Carmona, M.; Alonso, G.L. Determination of free amino acids and ammonium ion in saffron (Crocus sativus L.) from different geographical origins. Food Chem. 2009, 114, 1542-1548. [CrossRef] 
52. Covarrubias-Cárdenas, A.G.; Martínez-Castillo, J.I.; Medina-Torres, N.; Ayora-Talavera, T.; Espinosa-Andrews, H.; García-Cruz, N.U.; Pacheco, N. Antioxidant capacity and UPLC-PDA ESI-MS phenolic profile of Stevia rebaudiana dry powder extracts obtained by ultrasound assisted extraction. Agronomy 2018, 8, 170. [CrossRef]

53. Joshi, A.J.; Kumar, A.S. Seasonal variations of proteins and amino acids in three salt marsh species. Plant Sci. 1989, 99, 287-292. [CrossRef]

54. Xu, Z.; Zhou, G. Research advance in nitrogen metabolism of plant and its environmental regulation. Ying Yong Sheng Tai Xue Bao 2004, 15, 511-516. (In Chinese)

55. Mykhailenko, O.; Gudžinskas, Z.; Kovalyov, V.; Desenko, V.; Ivanauskas, L.; Bezruk, I.; Georgiyants, V. Effect of ecological factors on the accumulation of phenolic compounds in Iris species from Latvia, Lithuania and Ukraine. Phytochem. Anal. 2020, 1, 1-19. [CrossRef]

56. Cao, M.; Gao, M.; Suástegui, M.; Mei, Y.; Shao, Z. Building microbial factories for the production of aromatic amino acid pathway derivatives: From commodity chemicals to plant-sourced natural products. Metab. Eng. 2019, in press. [CrossRef]

57. Filiz, E.; Cetin, D.; Akbudak, M.A. Aromatic amino acids biosynthesis genes identification and expression analysis under salt and drought stresses in Solanum lycopersicum L. Sci. Hortic. 2019, 250, 127-137. [CrossRef]

58. Panday, S.K.; Prasad, J.; Dikshit, D.K. Pyroglutamic acid: A unique chiral synthon. Tetrahedron Asymmetry 2009, 20, 1581-1632. [CrossRef]

59. Stefanucci, A.; Novellino, E.; Costante, R.; Mollica, A. Pyroglutamic acid derivatives: Building blocks for drug discovery. Heterocycles 2014, 89, 1801-1825. [CrossRef]

60. Wang, G.; Xu, M.; Wang, W.; Galili, G. Fortifying horticultural crops with essential amino acids: A review. Int. J. Mol. Sci. 2017, 18, 1306. [CrossRef]

(C) 2020 by the authors. Licensee MDPI, Basel, Switzerland. This article is an open access article distributed under the terms and conditions of the Creative Commons Attribution (CC BY) license (http://creativecommons.org/licenses/by/4.0/). 